\title{
Dugong foraging behavior on tropical intertidal seagrass meadows: the influence of climatic drivers and anthropogenic disturbance
}

\author{
Anugrah A. Budiarsa (D) - H. H. De Iongh - Wawan Kustiawan • \\ Peter M. van Bodegom
}

Received: 24 October 2019/Revised: 20 March 2021/Accepted: 30 March 2021/Published online: 14 May 2021

(C) The Author(s) 2021

\begin{abstract}
Foraging strategies of dugongs in tropical areas are not yet well understood, and that is particularly true for grazing of fast-growing pioneer seagrass meadows in the intertidal zones. In this study, we investigated the driving factors affecting the number of grazing tracks in intertidal seagrass meadows caused by small herds of dugongs in Balikpapan Bay, Indonesia. We investigated seven intertidal seagrass meadows for which the dynamics of seagrass biomass, the ratio aboveground to belowground
\end{abstract}

Handling editor: Grazia Pennino

A. A. Budiarsa - H. H. De Iongh · P. M. van Bodegom Institute of Environmental Sciences, Leiden University, 2333 CC Leiden, The Netherlands

\section{A. A. Budiarsa}

Department of Marine Science, Mulawarman University, Balikpapan, Indonesia

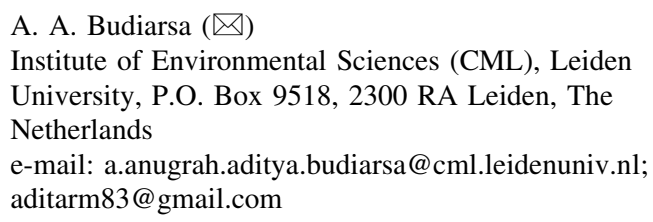

\section{H. H. De Iongh}

Antwerp University, Evolutionary Ecology, Wilrijk, Belgium

\section{W. Kustiawan}

Department of Forestry, Mulawarman University,

Balikpapan, Indonesia biomass, and the number of grazing tracks were recorded and measured based on monthly intervals over a year. Seagrass features showed a significant relationship with wind speed, precipitation, desiccation time, the distance of the grazing sward to a residential area, and fishing activity based on multiple (generalized) linear models. While the intertidal seagrass meadows consisted of 5 species in total, only Halodule pinifolia patches were grazed. Dugong feeding tracks were found in four of the seven sites. The strong variation in the number of tracks throughout the year was significantly affected by seagrass biomass of seagrass, location and wind speed. Our results show how the interplay of site conditions related to both shelter (wind speed) and food availability (seagrass biomass) determines its suitability for dugongs.

Keywords Dugong $\cdot$ Seagrass $\cdot$ Climate $\cdot$ Anthropogenic disturbance $\cdot$ Shelter

\section{Introduction}

Dugongs are megaherbivore mammals, which are strictly marine and forage both in near-shore seagrass meadows and in subtidal seagrass meadows (up to 40 $m$ deep). Ecologically, the dugongs occupy an essential niche in the shallow coastal ecosystem along the tropical and subtropical Indian ocean and western 
subtropics of the Pacific Ocean (Nishiwaki \& Marsh, 1985). They have presumably adapted their foraging strategies and have become specialized herbivores to cope with the spatial variability in their resources (Sheppard et al., 2007). Dugongs are believed to be represented by separate, relict populations, many close to extinction or extinct (Marsh et al., 2002). The International Union for Conservation of Nature (IUCN) ranked this species as vulnerable to extinction and trade in its products is regulated or banned by the Convention on International Trade in Endangered Species of Wild Flora and Fauna (CITES appendix I).

Nevertheless, dugong feeding preferences and foraging behavior are still not fully understood. This is particularly true for the intertidal zone. Dugongs are known to consume almost all seagrass species but they show a preference for small and soft pioneer species such as Halodule spp. and Halophila spp. (Adulyanukosol \& Poovachiranon, 2006). Short seagrasses such as Halophila ovalis, Halodule uninervis, Cymadoce rotundata, C. serrulate, Syringodium isoetifolium and Thalassia hempricii showed more evidence of being grazed than high fiber seagrasses such as Enhalus acoroides (Aragones et al., 2006; Tol et al., 2016). In addition, intertidal seagrasses are considered to be likely more nutritious compared to subtidal meadows due to higher nitrogen contents and higher digestibility (Lanyon, 1991; De Iongh et al., 1995; Preen, 1998; Yamamuro \& Chirapart, 2005; Sheppard et al., 2007). Indeed, a cafeteria experiment with a captive dugong in Surabaya Zoo by De Iongh (1996) showed that dugongs prefer food with a high In Vitro Digestibility (IVD) like Halodule uninervis and Halophila ovalis (fast-growing species). Likewise, in tropical areas, starch contents and carbohydrate contents of the belowground biomass rather than total nitrogen (Sheppard et al., 2007) seemed to drive dugong grazing behavior in the Lease islands and in Balikpapan bay, Indonesia (De Iongh et al., 2007). The intertidal zone is inhabited by typical opportunistic seagrasses of the genera Halophila, Halodule, Ruppia and Lepilaena and these species also generally display rapid a colonizing growth and a rapidly fluctuating total standing biomass (Kilminster et al., 2015). These features likely increase their palatability.

However, nutritional properties of seagrass are unlikely to be the only drivers of dugong occurrences. For instance, in North Australia, feeding patterns were influenced most strongly by the available plant biomass and only to a lesser degree by species composition and/or by nitrogen content (Preen, 1995; Sheppard et al., 2007, 2010; Tol et al., 2016). Moreover, their movements might also be influenced by the tidal cycle, with high tide facilitating dugongs' access to the intertidal area (De Iongh et al., 1998, 2007; Marsh et al., 2002; Sheppard et al., 2010). Dugongs spend a significant time in shallow, turbid waters and are often active at night (Anderson, 1994; De Iongh et al., 1998; Ichikawa et al., 2010; Sheppard et al., 2010; Parsons et al., 2013). In addition, Ichikawa et al. (2010) suggested that dugongs selectively prefer less noisy environments, and thus seem to avoid noise disturbance. Consequently, dugong preference for certain feeding swards may also be influenced by human caused disturbance, e.g., boating traffic, and fishing activity (Hodgson \& Marsh, 2007; Sheppard et al., 2007). The majority of dugong deaths are believed to result from incidental entanglement in fishing nets, destructive fishing practices, habitat destruction and boat strikes (Marsh et al., 2002; Rajamani \& Marsh, 2010). Even though the number of cases of dugong hunting have declined, due to the scarcity of dugongs and improved enforcement of government laws and regulations, in some parts of Indonesia dugong's meat is still being consumed. In coastal areas of Indonesia, dugongs are often caught in tidal fish traps or 'sero' (which are large traps constructed of mangrove wood, bamboo and netting) and gillnets, which can lead to stranding or washing up dead on beaches. People assume that as long as they do not actively hunt, they are not violating the regulations, and think when dugong are found dead, they can be legally consumed (Zamzani, 2017; Ambari, 2018; DKP, 2019).

Next to understanding local occurrences, also the drivers of seasonal variation in dugong occurrences and migration in Indonesia are not well understood. In subtropical regions, dugongs have been shown to have a limited thermal tolerance and therefore travel large distances to warm water during wintertime (Anderson, 1994; Marsh et al., 1994; Sheppard et al., 2006). While the seasons in the tropics are strongly influenced by monsoons, temperature differences are unlikely to play a role in those situations. Instead, both De Iongh et al. (2007) and Sheppard et al. (2009) suggest the possibility that wind speed and direction and wave action may affect dugong migration and behavior. In Indonesia, the East monsoon (April-October) is 
usually characterized by low rainfall and high waves in the southern parts, while the West monsoon (October-April) is characterized by high wind and high waves in the northern regions. The importance of wind speed and wave action to explain the temporal and spatial feeding patterns of dugongs has, however, not been quantified and also its relative importance compared to human disturbance or food availability is not well understood.

Understanding the drivers of dugong foraging in space and time and their role in the tropical seagrass meadows, where the dugongs live in small herds, will assist in developing appropriate coastal conservation strategies. The main aim of our study therefore was to investigate which factors influence the dugong feeding frequency in space and time in intertidal seagrass meadows. For this purpose, the vegetation composition and biomass of intertidal seagrass meadows, the dugong feeding frequency in time and space were recorded, measured and analyzed in Balikpapan Bay, Indonesia. These variables were related to factors potentially influencing the feeding frequency (wind speed, tide, temperature, aboveground to belowground biomass ratio, and fishing activity in seagrass meadows). Our study may contribute to a better understanding of the functioning of intertidal seagrass meadows and their ecological role as a habitat for small herds of dugongs.

\section{Material and methods}

\section{Study Area}

The Bay of Balikpapan is situated on the East coast of Kalimantan, Indonesia, (Fig. 1). Balikpapan Bay covers a surface of 16,000 ha, which drains a watershed of approximately 195,000 ha, bordering both rural and industrial areas (De Iongh et al., 2007). Along the bay, there is a stretch of mangrove, which is linked to intertidal inshore seagrass meadows. The bay has several industrial ports with a large oil refinery and intense tanker traffic. Around 22 seagrass meadows were found along the coastal line of Balikpapan Bay, dominated by Halodule pinifolia, but also Halophila ovalis, H. minor, Thalassia Hemprichii, and Enhalus acoroides were found to occur (De Iongh, 2005, 2006). We only selected intertidal meadows with a wide expanse. Therefore, only seven potential seagrass meadows were selected in Balikpapan Bay: Kariangau, Tg. Batu, Pulau Kedumpit, P. Kuangan, P. Balang, Beranga, and Tempadung.

A small population of dugongs have been documented in Balikpapan Bay from 2000 until 2008 (Marsh et al., 2002; De Iongh et al., 2007; Kreb, 2008). De Iongh et al. (2007) reported a subpopulation of 3 to 5 dugongs in Balikpapan Bay as part of a larger population found along the surrounding East coast of Kalimantan. Kreb (2008) reported only three sighting of dugongs in Balikpapan bay. These mammals were found swimming in Kariangau and Muara Berenga.

Data collection and analyses

\section{Seagrass composition and distribution}

In September 2016, species composition and seagrass coverage $(\%)$ was determined in each of the seven seagrass meadows. Ten quadrats $(60 \mathrm{~cm} \times 60 \mathrm{~cm})$ were selected haphazardly for each seagrass meadow, covering the entire meadow area (no more than two meters outside of the seagrass boundary). Species composition, seagrass cover (\%) and total size of each seagrass meadow $\left(\mathrm{m}^{2}\right)$ was determined for each of the seven seagrass meadows. The surface area was determined by mapping the seagrass meadows with a GPS Garmin 60 CSX. Each seagrass meadow was mapped once by walking along the borders of each species and taking coordinates every $20 \mathrm{~m}$ (with an accuracy of $10 \mathrm{~m}$, using a GPS Garmin 60 CSX). Surface area was calculated by connecting all coordinates as a polygon in Arc GIS 10.4 (ESRI 2015)

\section{Seasonal dugong tracks distribution and species selectivity}

New dugong feeding tracks in the seven meadows were counted every month from September 2016 to December 2017. A grazing track was regarded as new ( $<5$ days of age) when the roots of seagrass species could be seen and/or when the grazing track was relatively deep ( $>4 \mathrm{~cm}$ deep; De Iongh, 2006). We noted the most grazed seagrass species judging from the seagrass composition at places where dugong feeding tracks were observed. We checked at least five randomly selected grazing tracks per seagrass meadow for species composition, and additionally, five random tracks were selected and the dimension measured for 


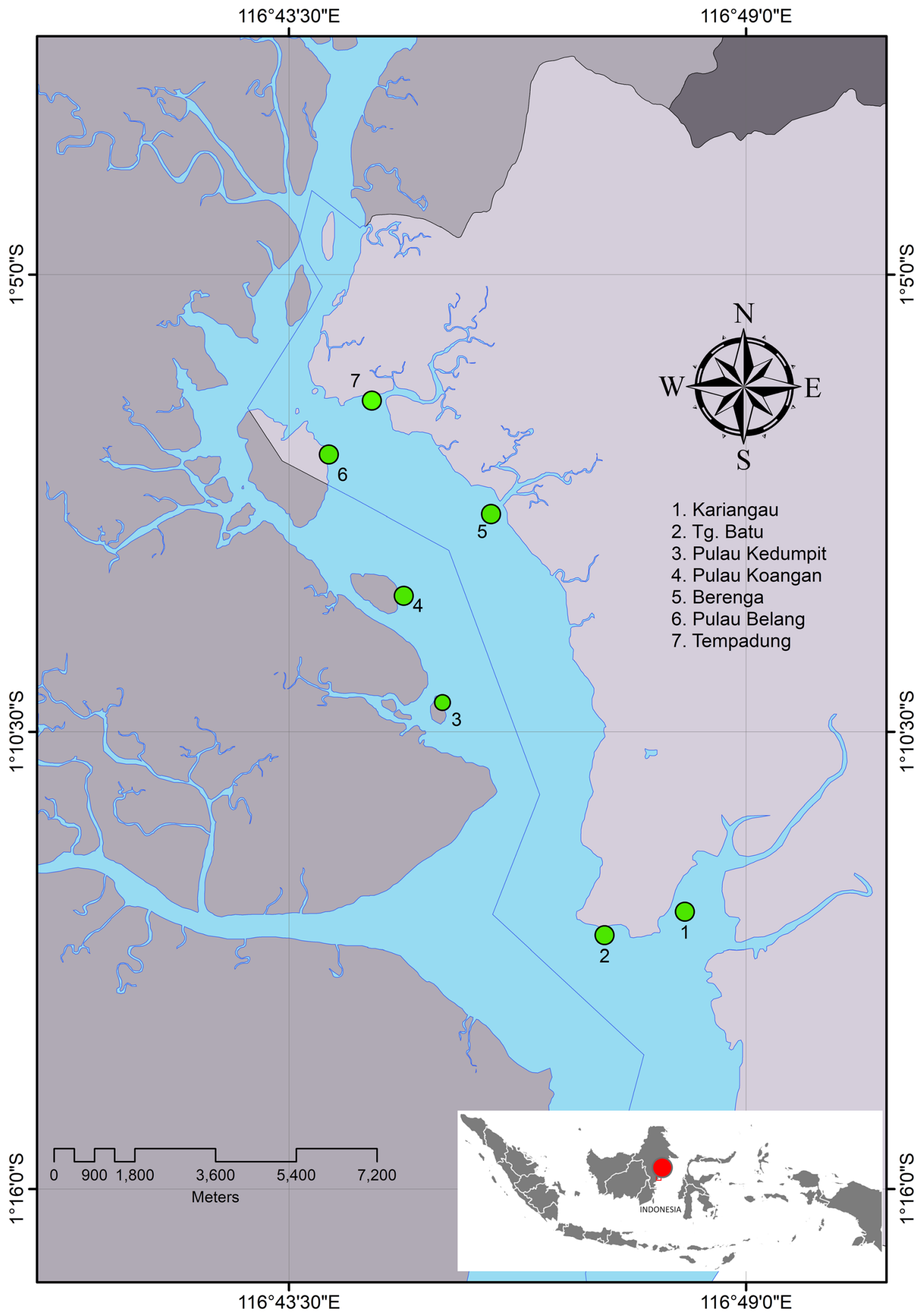


4Fig. 1 Overview of Balikpapan Bay, Indonesia and the seven seagrass meadows investigated. $1=$ Kariangau, $2=\mathrm{Tg}$. Batu, $3=$ P. Kedumpit, $4=$ P. Koangan, $5=$ Berenga, $6=$ P. Belang, $7=$ Tempadung

length, width, and depth, in February 2017 at four of the seagrass sites (Tg. Batu, Berenga, Tempadung and P. Belang).

\section{Seasonal dynamic seagrass biomass}

The dominant species in our seven meadows is $H$. pinifolia and it was also found to be the most grazed by dugongs (De Iongh et al., 2007; personal observation, 2016). Therefore, three samples were taken haphazardly in monospecific $H$. pinifolia patches for all seven seagrass meadows, between October 2016 and December 2017. To gather enough biomass, one sample consisted of three plastic cores $(\varnothing 16 \mathrm{~cm}$, depth $30 \mathrm{~cm}$ ) which were dug to approximately $20 \mathrm{~cm}$ depth to sample all rhizomes and roots (De Iongh et al., 1995). Samples were sieved with a $1 \mathrm{~mm}$ mesh sieve in seawater to remove sand and mud. Samples were then washed in freshwater, and aboveground material (stems and leaves) and belowground material (rhizomes and roots) were separated manually. Plants were carefully rubbed to remove any epiphytes. The wet weight (WW) was determined using an analytical balance (OHAUS) at $0.0001 \mathrm{~g}$ precision. Samples were wrapped in aluminium foil and dried in an oven $\left(70{ }^{\circ} \mathrm{C}\right)$ up to $48 \mathrm{~h}$ until a consistent dry weight was achieved $\left(\mathrm{g} \mathrm{DW} \mathrm{m}^{-2}\right)$.

To estimate the biomass of all species, three replicate samples of biomass were collected per seagrass meadow for all species from October 2016 to December 2016. Total dry weight aboveground and belowground were used to estimate seagrass biomass by extrapolation to the surface area of each species.

\section{Climate and the tidal cycle}

Climate and tidal cycle influence the oceanographic dynamics in Balikpapan Bay and might determine the foraging behavior of dugongs. Therefore, the following climatic covariates were assessed: wind speed (as major factor in wave generation), temperature, and precipitation. Data were obtained from Worldclim version 2 (www.worlclim.org) at a spatial resolution of $1 \mathrm{~km}^{2}$. The data refer to coordinate positions within which our seven research sites were situated. Tidal cycle data were obtained from the Tidal Book 2016 and 2017 produced by Indonesia Geospatial Information Board (BIG, 2016, 2017).

\section{Anthropogenic disturbance}

Anthropogenic activities in the study area that might disturb dugongs were fishing activities and the distance of residential areas to the seagrass meadows. Fishing activities in this study were classified as any human activity to collect fish within a seagrass meadow, including recreational fishers and crab pots. This activity was counted in each seagrass meadow during 12 observation days in February 2017, and recorded as the number of individual activities. The distance of residential houses to seagrass meadows was measured by collecting the coordinate of the midpoint of each seagrass meadow, and using Google Maps and Arc GIS 10.4 (ESRI, 2015) to measure the distance of this coordinate to the nearest residential settlement.

During February 2017, fifteen open interviews were held with local fishermen with the following questions for qualitative analysis; (a) What is your age and primary profession? (b) Did you observe dugongs or catch dugongs over the past ten years? (c) Did you observe dugongs or catch dugongs during the last two years?

\section{Statistics}

The potential drivers and their relative importance for the spatial and temporal pattern of the number of dugong tracks was analyzed using a Generalized Linear Model (GLM). Given that the number of dugong tracks constitute count data, we applied a Poisson distribution with a log-link function (a logitlink function performed very similarly) as commonly advised. To evaluate whether dugong grazing has a different spatiotemporal dynamic than the indicators of its main food source, the biomass of $H$. pinifolia and its aboveground to belowground biomass ratio (as measure of relative availability of carbohydrates), we also tested these variables as dependent variable. After a log-transformation, seagrass biomass and the aboveground/belowground $(\mathrm{AB} / \mathrm{BG})$ ratio complied to a normal distribution, and hence a Gaussian distribution 
was applied to these variables in a GLM analysis. In all analyses, we included fishing activity and distance from a residential area as human disturbance variables and desiccation time, precipitation and temperature, site and month. as potential ecological drivers. We used "site" and "month" as categorical factors to account for additional undefined spatiotemporal drivers. For all three response variables, we selected the best model based on a backward model selection with the step() function in $\mathrm{R}$ using the Akaike Information Criterion (AIC). If "site" or "month" was significant according to the best model, a Tukey's honestly significant difference test was run to identify which "sites" or "months" were most dissimilar for biomass and AG/BG ratio. For the number of grazing tracks, which were not normally distributed, site differences were obtained from the summary() function of GLM as, in that case, the assumptions of a Tukey's were not fulfilled.

Before analysis, the few missing observations were estimated to avoid complete removal of sampling months. We missed above and belowground biomass for a few monitoring months, and used the linear relationship between total biomass and the $\mathrm{AG} / \mathrm{BG}$ ratio to impute the missing data. The attribution of biomass to above- and belowground biomass was missing in a few other months. For that variable, we used the measured total biomass in combination with species-location average ratios of above- and belowground obtained from the other months to estimate the missing values.

As part of our analysis, we made scatter plots of the explanatory variable and the (transformed) response variable to evaluate deviations from linearity, as well as of the predicted vs. residuals. Any deviation from linearity should translate into a deviation in the symmetry of residuals. In neither case, we observed such deviation. We conclude that the relationships tested in this research approach a linear relationship. Some overdispersion occurred in the number of dugong tracks, a common feature of count data. To evaluate collinearity among variables, we applied the Spearman rank correlation for continuous variables and the Variance Inflation Factor (VIF) for categorical variables. Following Zuur et al. (2010), we used a stringent VIF threshold of 3.0 and a threshold for the Spearman correlation of 0.7 . None of the final models were affected by collinearity according to these criteria (results not shown). All statistical performance we used R statistical software ver. 1.4.1103 (R core team, 2018)

\section{Results}

Seagrass composition and distribution

We found that the seagrass meadows at the seven sites comprised five species; (1) Halodule pinifolia ( $\mathrm{Cy}$ modoceaceae), (2) Halophila minor (Hydrocharitaceae), (3) Halophila ovalis (Hydrocharitaceae), (4) Thalassia hemprichii (Hydrocharitaceae), and (5) Enhalus acoroides (Hydrocharitaceae). Thus, seagrass meadows in Balikpapan Bay are intertidal seagrass meadows dominantly inhabited by typically colonizing and opportunist seagrasses of the genus Halodule and Thalassia while there is a subtidal zone dominated by Enhalus spp (only found in Kariangau). The total seagrass area across the seven locations was estimated to have a total surface of $207,418 \mathrm{~m}^{2}$. Kariangau is the largest seagrass meadow with 81,309 $\mathrm{m}^{2}$ and has a high species diversity with all five species found (Table 1).

In terms of coverage, the fast-growing $H$. pinifolia (and to some extents Halophila minor) is the dominant species in all intertidal seagrass meadows in Balikpapan Bay, except for Kariangau. The species coverage in Kariangau was dominated by $T$. hemprichii, and $H$. pinifolia is the second largest species coverage; meanwhile E. acoroides is the largest seagrass species, and although it only covers a small area, it has high total biomass compared to other species due to its large size (Table 1).

Seasonal dugong tracks distribution and its dimensions

Kariangau and P. Koangan were the only sites not to have grazing tracks during our sampling period. All tracks were found in the $H$. pinifolia zone. The dynamics in the number of dugong tracks seemed to be explained $55.96 \%$ of the variance $(P<0.01)$ by site, biomass, biomass ratio, wind speed and fishing activity which were selected as primary independent factors influencing the grazing behavior of dugongs. These independent variables significantly affected the number of grazing tracks present in the meadow $(P<$ 0.01 and $P<0.05$ ) (Table 2). Tempadung is the site 
Table 1 Species composition, species coverage, species biomass, species percent cover and sediment type with standard errors in seven seagrass meadows, Balikpapan Bay, Indonesia

\begin{tabular}{|c|c|c|c|c|c|c|}
\hline No. site & Site & Species composition & Area $\left(\mathrm{m}^{2}\right)$ & Biomass $\left(\mathrm{g} \mathrm{m}^{-1}\right)$ & Percent cover & Sediment type \\
\hline \multirow[t]{5}{*}{1} & \multirow[t]{5}{*}{ Kariangau } & Halophila pinifolia & 8,327 & $32.42 \pm 4.13$ & 75 & loamy sand \\
\hline & & Thalassia Hemprichii & 65,214 & $246.9 \pm 22.5$ & 50 & loamy sand \\
\hline & & H. ovalis & 3,176 & $64.1 \pm 13.3$ & 35 & loamy sand \\
\hline & & Enhalus acoroides & 4,592 & $1907.0 \pm 301.3$ & 30 & loamy sand \\
\hline & & H. minor & a & $26.04 \pm 5.8$ & 25 & loamy sand \\
\hline \multirow[t]{2}{*}{2} & \multirow[t]{2}{*}{ Tg. Batu } & Halophila pinifolia & 11,754 & $46.16 \pm 3.9$ & 75 & loamy sand \\
\hline & & H. minor & 620 & $91.2 \pm 7.4$ & 25 & loamy sand \\
\hline \multirow[t]{3}{*}{3} & \multirow[t]{3}{*}{ Pulau Kedumpit } & Halophila pinifolia & 12,711 & $39.20 \pm 2.9$ & 80 & loamy sand \\
\hline & & Thalassia Hemprichii & 107 & $409.53 \pm 53.1$ & 35 & loamy sand \\
\hline & & H. minor & a & $64.30 \pm 10.5$ & 35 & loamy sand \\
\hline \multirow[t]{2}{*}{4} & \multirow[t]{2}{*}{ P. Koangan } & Halophila pinifolia & 13,777 & $54.86 \pm 4.8$ & 90 & loamy sand \\
\hline & & H. minor & a & $62.30 \pm 10.0$ & 50 & loamy sand \\
\hline \multirow[t]{2}{*}{5} & \multirow[t]{2}{*}{ Berenga } & Halophila pinifolia & 34,254 & $27.6 \pm 3.2$ & 75 & loamy sand \\
\hline & & H. minor & 260 & $50.4 \pm 7.0$ & 30 & loamy sand \\
\hline \multirow[t]{3}{*}{6} & \multirow[t]{3}{*}{ Tempadung } & Halophila pinifolia & 8,528 & $14.21 \pm 1.45$ & 90 & loamy sand \\
\hline & & H. minor & 702 & $40.76 \pm 10.68$ & 50 & loamy sand \\
\hline & & H. ovalis & 51 & $62.31 \pm 10.4$ & 25 & loamy sand \\
\hline \multirow[t]{3}{*}{7} & \multirow[t]{3}{*}{ P. Belang } & Halophila pinifolia & 38,716 & $53.14 \pm 1.68$ & 90 & loamy sand \\
\hline & & H. minor & 510 & $56.6 \pm 11.8$ & 60 & loamy sand \\
\hline & & H. ovalis & 4,119 & $90.60 \pm 8.91$ & 50 & loamy sand \\
\hline
\end{tabular}

${ }^{\mathrm{a}}$ Challenging to calculate the area as $H$. minor lived mixed underneath $H$. pinifolia canopy

Table 2 Significance of the tested factors in the Generalized Linear Models, each column representing the results of the best model

\begin{tabular}{|c|c|c|c|c|c|c|c|c|c|c|c|}
\hline & Intercept & Month & Site & Biomass & $\begin{array}{l}\mathrm{AG} / \\
\mathrm{BG} \\
\text { ratio }\end{array}$ & $\begin{array}{l}\text { Distance } \\
\text { residential } \\
\text { area }\end{array}$ & $\begin{array}{l}\text { Wind } \\
\text { speed }\end{array}$ & Temperature & Precipitation & $\begin{array}{l}\text { Fishing } \\
\text { activity }\end{array}$ & $\begin{array}{l}\text { Deviance } \\
\text { explained } \\
(\%)\end{array}$ \\
\hline $\begin{array}{c}\text { Grazing } \\
\text { tracks }\end{array}$ & $* * *$ & $X$ & $* *$ & $* * *$ & $* * *$ & $\mathrm{X}$ & $* * *$ & $\mathrm{X}$ & $\mathrm{X}$ & $0.12^{\#}$ & 55.96 \\
\hline Biomass & $* * *$ & $X$ & $* *$ & $X$ & $* * *$ & $X$ & $X$ & $\mathrm{X}$ & $* *$ & $\mathrm{X}$ & 53.24 \\
\hline $\begin{array}{c}\mathrm{AG} / \mathrm{BG} \\
\text { ratio }\end{array}$ & 0.2 & $* *$ & $*$ & $X$ & $\mathrm{X}$ & $\mathrm{X}$ & $X$ & 0.20 & $X$ & $X$ & 86.00 \\
\hline
\end{tabular}

$\mathrm{X}=$ variable eliminated in our model selection; $\# p=0.1 ; * p<0.05 ; * * p<0.01 ; * * * p<0.001$

that had the largest average number of grazing tracks, which was significantly different $(P<0.05)$ from other sites except for Tg. Batu (Fig. 2).

At the onset of the rainy season, from October to December (in 2017 and to some extent in 2016), consistently more grazing tracks were observed than during other times of the year. For instance, some 120 tracks were counted in $\mathrm{Tg}$. Batu in October 2016, while in June 2017 , only 13 tracks were counted at the same site. The overall average number of grazing tracks across all months was the highest in Tempadung $(53 \pm 24)$, Tg. Batu (66 \pm 30$)$ and P. Belang (68 \pm 38$)$. These sites were also most frequently visited by dugongs; 8, 5 and 4 months, respectively out of the 11 sampling months included in this study. Only a few times, we found grazing tracks in Berenga (3 months 


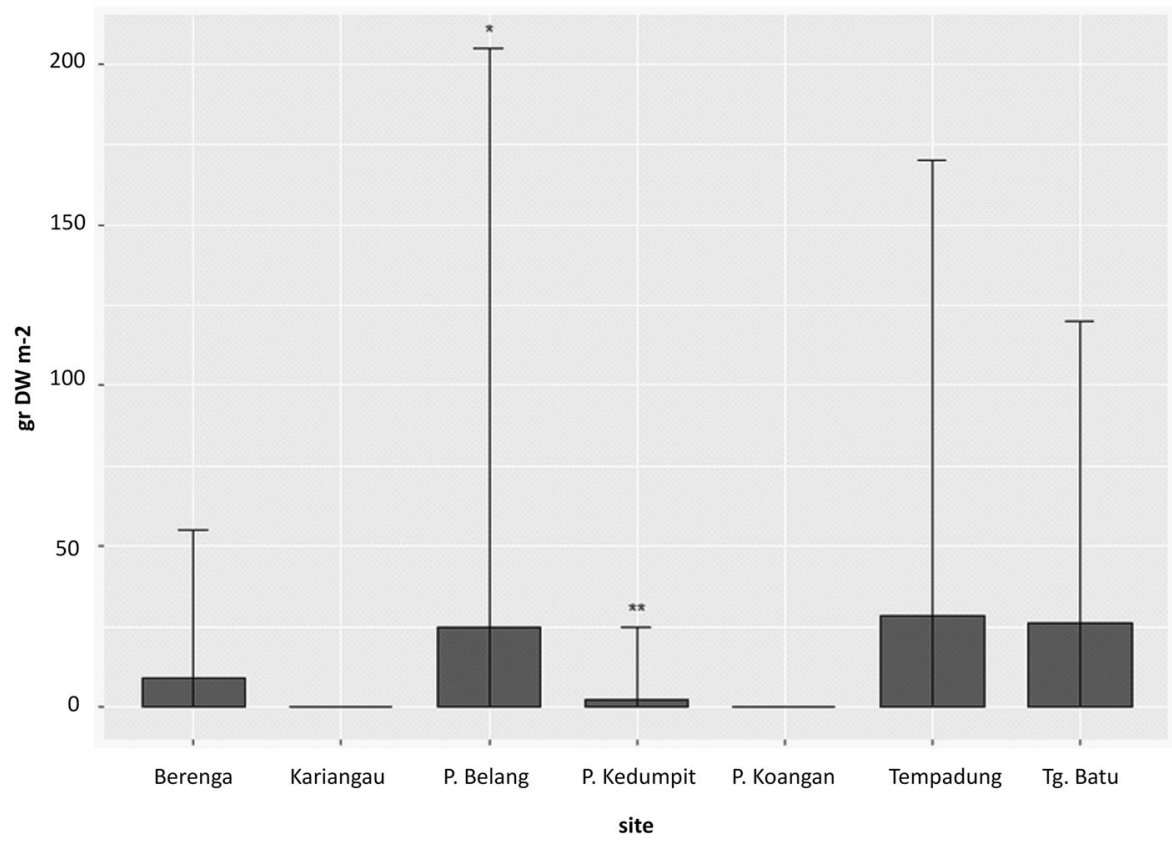

Fig. 2 Spatial pattern of dugong grazing tracks ( \pm SE) in seven seagrass meadows in Balikpapan Bay, Indonesia; monthly observations from September 2017 to December 2017. Significant deviations-according to the summary() function of our GLM model-compared to Berenga (which was the site closest

with an average number of tracks of $36 \pm 11)$ and $\mathrm{P}$. Kedumpit (1 month, with 25 tracks) and we never found tracks at Kariangau and P. Koangan.

Dimensions of the grazing tracks vary for length and depth, but not for width. There was no difference in dugong track lengths at Tg. Batu, Pulau Belang and Tempadung, with an average of $(349 \pm 60.7 \mathrm{~cm})$, while dugong tracks were shorter at Berenga (225.6 \pm $14.4 \mathrm{~cm}$ ). The average width of the grazing tracks was consistently 19-21 cm. The deepest tracks were found in Tempadung with an average of $5.22 \pm 0.3 \mathrm{~cm}$, and the shallowest occurred in Tg. Batu with $3.89 \pm 0.3$ $\mathrm{cm}$.

The result of the questionnaire survey showed that dugongs were only sporadically observed by fishermen. Only elderly fishermen ( $>50$ years old) had seen dugongs directly (by observation or hunting). Most of the local people found it challenging to distinguish dugongs from freshwater dolphins (Orcaella brevirostris).

to the average number of grazing tracks) are indicated in asterisks, with *signifying a significantly higher number of grazing tracks and $* *$ signifying a significantly lower number of grazing tracks compared to Berenga

Spatiotemporal dynamics in $H$. pinifolia biomass

The biomass in $H$. pinifolia meadows at Balikpapan Bay ranged from $32.18 \pm 2.8$ to $120.19 \pm 5.4 \mathrm{~g} \mathrm{DW}$ $\mathrm{m}^{-2}(\mathrm{n}=40)$. P. Koangan $\left(57.2 \pm 2.5 \mathrm{~g} \mathrm{Dw} \mathrm{m}^{-2}\right)$ and P. Belang $\left(51.8 \pm 3.0 \mathrm{~g} \mathrm{Dw} \mathrm{m}^{-2}\right)$ had the highest biomass of $H$. pinifolia (Fig. 3a). The lowest biomass of $H$. pinifolia was found in June 2017 (33.59 $\pm 1.4 \mathrm{~g}$ DW $\mathrm{m}^{-2}$ ) and the highest biomass was found in December 2017 (56.64 $\pm 4.6 \mathrm{~g} \mathrm{DW} \mathrm{m}^{-2}$ ), see Fig. $3 \mathrm{~b}$. This coincides with the onset of the rainy season, although surprisingly precipitation, desiccation time and month were all eliminated from the model. The best linear model for $H$. pinifolia biomass explained $53.24 \%$ of the variance $(P<0.01)$ and was affected by site, the ratio of aboveground to belowground biomass, and then precipitation (Table 2). Interestingly, Tempadung had significantly less biomass than four of the seagrass sites but had significantly more dugong tracks than four of the five sites which had tracks present $\left(26.3 \pm 21.3 \mathrm{~g} \mathrm{Dw} \mathrm{m}^{-2}\right)$, even though it is not significantly different from Berenga and Kariangau (Fig. 3a). 

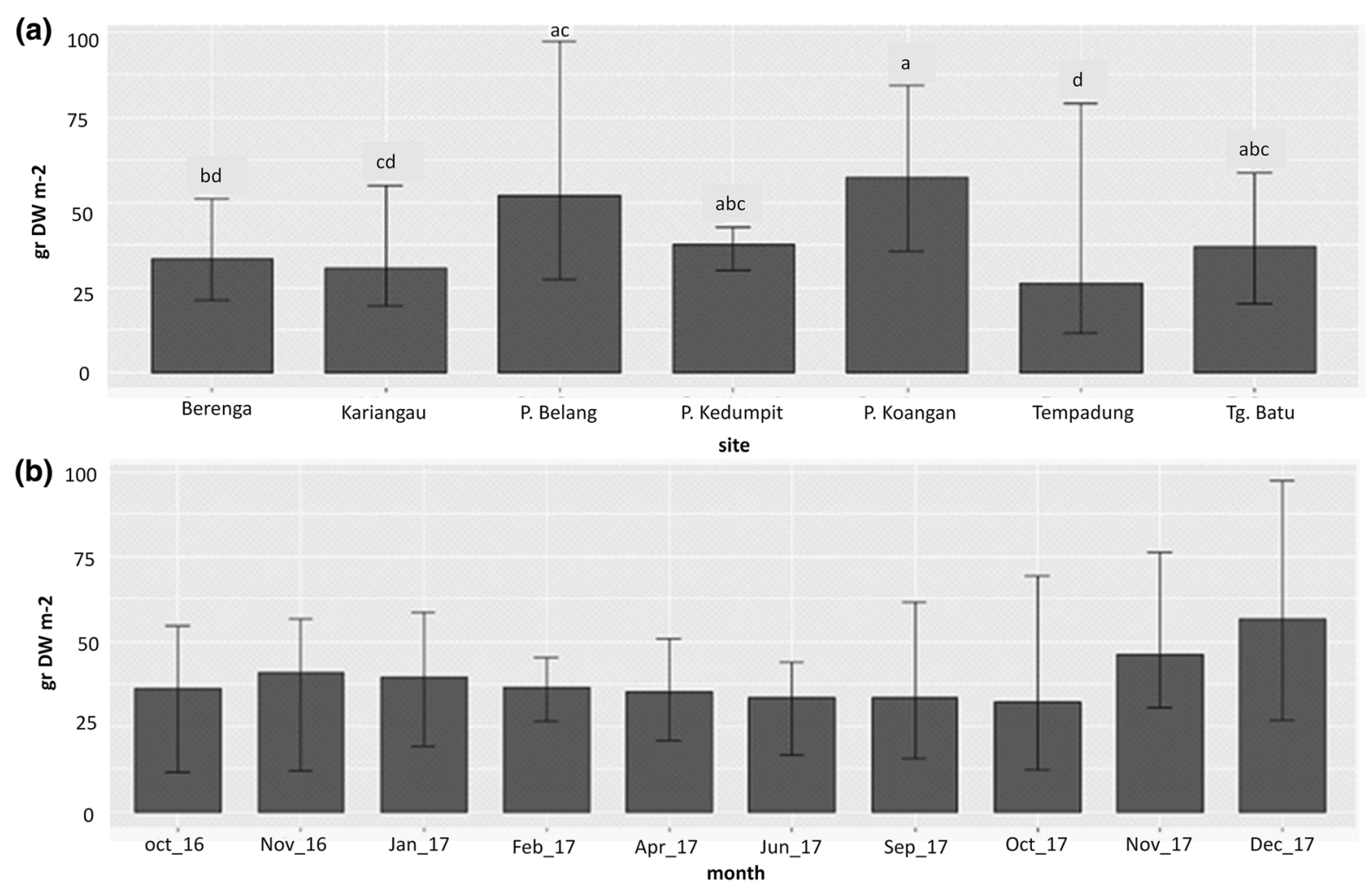

Fig. 3 Biomass $\left(\mathrm{g} \mathrm{DW} \mathrm{m}^{-2}\right.$ ) of Halodule pinifolia (standard error in vertical lines and its distribution over, a seven seagrass meadows in Balikpapan bay, Indonesia and $\mathbf{b}$ the 11 months of

The intertidal seagrass meadows dominated by fastgrowing species, such as in Balikpapan Bay, are characterized by relatively high belowground biomass, as expressed by the above- to belowground biomass ratios which were all $<1$. Pulau Belang and $\mathrm{P}$. Koangan had significantly lower biomass ratios than other sites (Fig. 4a). We found that biomass ratios from October 2016 to June 2017 were significantly higher than for September to December 2017 (see Fig. 4b). The final model of seagrass explained the spatiotemporal dynamics of the ratio of above- and belowground well with $86.00 \%$ of the variance explained $(P<0.001)$. This model included all initial variables; temperature, precipitation, desiccation time, site, and month, where site $(P<0.05)$, and month $(P<$ $0.05)$ were significant (Table 2 ). sampling in this study. Error bars indicate the $95 \%$ confidence interval of the LS means. Means sharing a letter are not significantly different (Tukey-adjusted comparison)

\section{Discussion}

We found that ten years after a study by De Iongh et al. (2007), dugongs still forage in Balikpapan Bay. This finding confirms that conditions in Balikpapan Bay still allow foraging of dugongs. The presence for grazing tracks is the main evidence of the presence of dugongs in the bay where the small number of dugongs makes it difficult to observe them directly. Based on the number of tracks and track dimensions (Table 3), we estimate that 2-3 dugongs currently occur in Balikpapan Bay, which might indicate a slight reduction in the dugong herds size compared to the population of 3-5 dugongs observed by De Iongh et al. (2007). These dugongs are expected to belong to a larger population, and they may migrate seasonally to Balikpapan Bay.

During our monitoring period, dugong tracks in Balikpapan Bay were specifically found at $H$. pinifolia patches. Dugongs may graze other seagrass species, but this is difficult to observe and no detectable impacts 

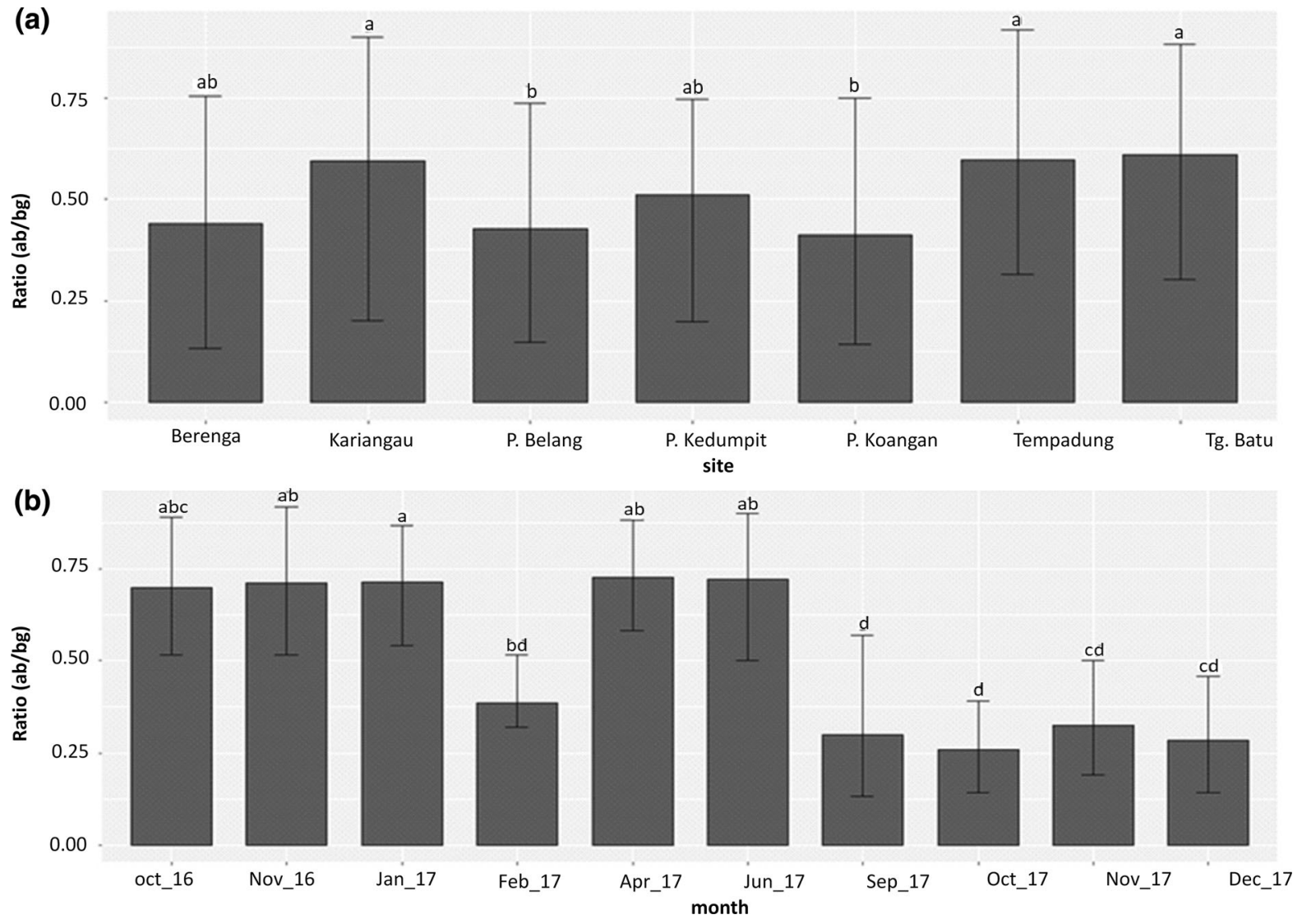

Fig. 4 Halodule pinifolia dynamics in the aboveground (AB) to belowground (BG) biomass ratio in $\mathbf{a}$ location and $\mathbf{b}$ time of data collection. Error bars indicate the $95 \%$ confidence interval

Table 3 Dimensions ( \pm SE) of dugong grazing tracks collected in seagrass meadows Balikpapan Bay, Indonesia, in February 2017

\begin{tabular}{lrrr}
\hline Site & Length $(\mathrm{cm})$ & Width $(\mathrm{cm})$ & Depth $(\mathrm{cm})$ \\
\hline Tg. Batu & $295.2 \pm 51.3$ & $19 \pm 2.6$ & $3.89 \pm 0.3$ \\
Berenga & $225.6 \pm 14.4$ & $21 \pm 2.6$ & $4.26 \pm 0.3$ \\
Pulau Belang & $367.4 \pm 80.0$ & $21.6 \pm 1.5$ & $4.32 \pm 0.3$ \\
Tempadung & $384.7 \pm 50.9$ & $21.05 \pm 2.4$ & $5.22 \pm 0.3$ \\
\hline
\end{tabular}

were found on other species. Our observations coincide with a previously documented preference of dugongs for patches with pioneer species, Halodule spp. (Heinsohn et al., 1977; De Iongh et al. 1995, 2010; Preen, 1995; Yamamuro \& Chirapart, 2005). Nonetheless, our model shows that seagrass biomass is one of the driving factors for dugong to graze in seagrass of the LS means. Means sharing a letter are not significantly different (Tukey-adjusted comparison)

meadows. Tol et al. (2016) also demonstrated that dugongs feeding patterns in Australia tropical regions were influenced most strongly by the available plant biomass and only to a lesser degree by species composition and or by nitrogen content.

Another factor that influences dugong grazing is location. The observations and GLMs indicate that Tempadung is the most frequently visited location. Tempadung is a location that is quite far inside the bay (Fig. 1). This resonates with the fact that the distance from residential areas and fishing activity might influence the foraging strategy in spite of our models showing these variables as not significantly affecting the number of dugong grazing. We assume that dugongs might avoid disturbance to prevent getting caught by fishing gear or to get hunted by humans. Interviews also revealed that local people in Jenebora (small village close to $\mathrm{P}$. Kedumpit) still remember how they caught dugongs in the past. Local people 
informed us that they like to eat dugong meat, but they suggested that dugongs are difficult to find nowadays. Another reason why dugongs may graze in seagrass meadows far away from residential areas is to avoid the possibility of the boat collisions. Hodgson \& Marsh (2007) reported that in Moreton Bay, where there is a large population of dugongs, boat traffic might reduce the foraging time of dugongs and they also indicated the direct impact of boats on dugongs through boat collisions. Similarly, manatees in Florida appear to be seeking areas of low boat traffic, increasing their use of sanctuaries where boating is prohibited (Buckingham et al., 1999; Reynolds, 1999). These factors do, however, not seem to affect dugong grazing in Balikpapan Bay.

Another significant indication for the influence on other non-biological factors influencing dugong foraging grazing in time and space (the spatial dynamics primarily represented by the effects of 'site') was the significance of climatic factors. Most grazing tracks were observed at the onset of the East monsoon season (from September to December), which is consistent with observations from a decade earlier (De Iongh et al. 2007). Differences in food availability only seem to some extent explain these patterns. Instead, our analyses suggest that dugong grazing preferences may also be influenced by climatic factors in combination with tidal fluctuations. We observed that mainly wind speed is an important driver. During the East monsoon, winds gradually increase from April to October, when high waves are formed in open seas along the East coast of Kalimantan and areas downstream of Balikpapan Bay. High waves may cause difficulties for dugong to forage in intertidal areas during high tide. Dugongs may then prefer calm water, such as in Balikpapan Bay. De Iongh et al. (1998) reported a similar result for dugong grazing in the Lease Islands, Maluku province where dugongs moved to calm waters such as bays or at the Northside of the islands.

While $H$. pinifolia biomass was an important driver of the number of dugong grazing tracks, it was driven by yet another set of drivers. Total $H$. pinifolia biomass was most strongly related to the $\mathrm{AB} / \mathrm{GB}$ biomass ratio, environmental temperature, and site. In addition, these meadows show explicit seasonal dynamics, with increased biomass during rainy season (November to February) and decreased biomass during summertime (April-October). This dynamics is partly explained by temperature (Lee \& Dunton,
1996; Lee et al., 2007) with increasing temperatures in summertime. However, the month was an important explanatory variable too, indicating additional temporal variables not explained by our climatic factors included. Apparently, seasonal dynamics in biomass was unrelated to precipitation. We considered precipitation to be a proxy for the seasonal differences caused by the monsoons and by tidal fluctuations. We also assumed that in topical intertidal seagrasses, precipitation may reduce heat stress. These variations, nor the acute, pulse-type disturbances by precipitation affecting coastal area extensions and altering seagrass physicochemical characteristics (e.g. salinity, temperature, and turbidity; Connell, 1997; Chollett et al., 2007), seem to be important for the seagrass biomass that exists in the Balikpapan Bay intertidal zone (Fig. 3).

Furthermore, we assumed that increased desiccation during the tidal cycle each month negatively impacts the growth and development of $H$. pinifolia in intertidal areas, especially affecting the aboveground characteristics. In Maluku, daylight exposure during extreme neap tide resulted in a significant loss of aboveground plant biomass through desiccation and the dehydration of leaves (De Iongh, 1996). Other studies confirm seasonal declines within an intraannual cycle in tropical seagrass (aboveground) biomass due to tidal exposure (Erftemeijer \& Herman, 1994). Also, Unsworth et al. (2012) showed that tidal exposure might induce considerable seasonal variability in biomass, production, and nutrient contents in shallow-water seagrass meadows of E. acoroides in South Sulawesi. In our study, non-significant effects of desiccation were found on $H$. pinifolia. This may be due to its morphological and growth adaptations to the intertidal zone. Desiccation tolerance in seagrasses is likely to involve a combination of morphological traits and growth strategies, such as downsizing (e.g., smaller, narrower leaves; Den Hartog, 1970; PerezLlorens and Niell, 1993), reduced structural rigidity (Björk et al., 1999; Tanaka \& Nakaoka, 2004), osmotic adaptation (Sandoval-Gil et al., 2015) and increased rates of leaf abscission and leaf turnover (Shafer et al, 2007). Indeed, H. pinifolia tends to have less aboveground biomass (Sidik et al., 1999; Longstaff \& Dennison, 1999) and thus greater belowground reserves to increase resilience to disturbances. Also, H. pinifolia has narrow leaves that tend to be narrower and smaller when more exposed. Likewise, Al-Bader 
et al. (2014) reported that Halodule uninervis in Kuwait bay had longer leaves in the lower intertidal zone as compared to the upper intertidal zone.

Altogether, we conclude that in Balikpapan Bay food supply and food quality are abundant and create a suitable habitat for dugong. The availability of seagrass biomass and carbohydrates are essential factors for dugong grazing. In addition, dugongs need shelter and protection from the sea in bad seasons. Therefore, the protection of intertidal fast-growing seagrass meadows in embayment coastal waters may be an important conservation measure by serving as a dugong sanctuary. This sanctuary allows connecting the small population of dugongs in Balikpapan Bay to the main population that migrates along the coasts of East Kalimantan. This result might help seagrass meadows in the archipelago, to support dugong foraging requirements. It also allowed us to clearly identify locations where this remnant population persists, and where urgent management efforts can be directed. Our systems analysis of dugong-seagrass interactions under the influence of environmental conditions can be used to facilitate conservation actions to inform and educate people, to improve global awareness, and to enhance the enforcement of community-based conservation and management of dugongs and its associated intertidal seagrass habitat.

Acknowledgments We appreciate the scholarship funding by The Ministries of Research, Technology, And Higher Education Republic of Indonesia (KEMENRISTEK_DIKTI) collaborated with Indonesia Endowment Fund for Education (LPDP). Ghitarina M.Sc, Director of Laboratory of water quality, FPIK-UNMUL was helpful in research equipment. CML colleagues provided advice to improve the manuscript, and students from Mulawarman University were helpful during the field research. We would like to thank to the editors of the Journal of Hydrobiologia and two anonymous reviewers who greatly helped to improve the manuscript.

Open Access This article is licensed under a Creative Commons Attribution 4.0 International License, which permits use, sharing, adaptation, distribution and reproduction in any medium or format, as long as you give appropriate credit to the original author(s) and the source, provide a link to the Creative Commons licence, and indicate if changes were made. The images or other third party material in this article are included in the article's Creative Commons licence, unless indicated otherwise in a credit line to the material. If material is not included in the article's Creative Commons licence and your intended use is not permitted by statutory regulation or exceeds the permitted use, you will need to obtain permission directly from the copyright holder. To view a copy of this licence, visit http://creativecommons.org/licenses/by/4.0/.

\section{References}

Adulyanukosol, K., \& S. Poovachiranon, 2006. Dugong (Dugong dugon) and seagrass in Thailand: present status and future challenges. Proc. 3rd Int. Symp. SEASTAR and Asian Bio-Logging Science, 3(December 2006), 41-50.

Al-bader, D. A., D. A. Shuail, R. Al-Hasan \& P. Suleman, 2014. Intertidal seagrass Halodule uninervis: factor controlling its density, biomass and shoot length. Kuwait Journal of Science 41: 171-192.

Ambari, M., 2018. Kisah pemburu Dugong di Teluk Bogam. Mongabay. Retrived from: https://www.mongabay.co.id/ 2018/04/16/kisah-para-pemburu-dugong-di-teluk-bogam/.

Anderson, P. K., 1994. Dugong distribution, the seagrass Halophila spinulosa, and thermal environment in winter in deeper waters of eastern Shark Bay, Western Australia. Wildlife Research 21: 381-388.

Aragones, L. V., I. R. Lawler, W. J. Foley \& H. Marsh, 2006. Dugong grazing and turtle cropping : grazing optimization in tropical seagrass systems? Oecologia 149: 635-647.

Björk, M., J. Uku, A. Weil \& S. Beer, 1999. Photosynthetic tolerances to desiccation of tropical intertidal seagrasses. Marine Ecology Progress Series 191: 121-126.

Buckingham, C., L. Lefebvre, J. Schaefer \& H. Kochman, 1999. Manatee response to boating activity in a thermal refuge. Wildlife Society Bulletin 27: 514-522.

Chollett, I., D. Bone \& D. Pérez, 2007. Effects of heavy rainfall on Thalassia testudinum beds. Aquatic Botany 87: 189-195.

Connell, J., 1997. Disturbance and recovery of coral assemblages. Coral Reefs 16: 101-113.

De Iongh, H. H., 1996. Plant-Herbivore Interactions Between Seagrasses and Dugongs in a Tropical Small Island Ecosystem. Phd Diss., University Nijmegen. pp. 1-205.

De Iongh, H. H., 2005. Recent dugong seagrass in Balikpapan Bay, Indonesia. Sirenews 43: 4-15.

De Iongh, H. H., 2006. Recent development in dugong research in Balikpapan bay, east Kalimantan. Sirenews 45: 21-23.

De Iongh, H. H., B. J. Wenno \& E. Meelis, 1995. Seagrass distribution and seasonal biomass changes in relation to dugong grazing in the Moluccas, East Indonesia. Aquatic Botany 50: 1-19.

De Iongh, H., P. Langeveld \& M. Van der Wall, 1998. Movement and home ranges of Dugongs around the Lease islands, East Indonesia. Marine Ecology 19: 179-193.

De Iongh, H. H., W. Kiswara, W. Kustiawan \& P. E. Loth, 2007. A review of research on the interactions between dugongs (Dugong dugon Muller 1776) and intertidal seagrass beds in Indonesia. Hydrobiologia 591: 73-83.

Den Hartog, C., 1970. The Seagrasses of The World. North Holland, Amsterdam.

Erftemeijer, P. \& P. M. J. Herman, 1994. Seasonal changes in environmental variables, biomass, production and nutrient 
contents in two contrasting tropical intertidal seagrass beds in South Sulawesi, Indonesia. Oecologia 99: 45-59.

ESRI ARCGIS, 2015. Environmental Systems Research Institute, Redlands

Heinsohn, G. E., J. Wake, H. Marsh \& A. V. Spain, 1977. The dugong (Dugong dugon (Muller)) in the seagrass system. Aquaculture 12: 235-248.

Hodgson, A. J. \& H. Marsh, 2007. Response of dugongs to boat traffic: the risk of disturbance and displacement. Journal of Experimental Marine Biology and Ecology 340: 50-61.

Ichikawa, K., T. Akamatsu, N. Arai, T. Shinke \& K. Adulyanukosol, 2010. Spatial distribution of dugongs by acoustic and visual observation in Thailand. Proceedings of the 5th International Symposium on SEASTAR2000 and Asian Bio-Logging Science (The 9th SEASTAR2000 Workshop), 39-42.

Kemeterian Kelautan dan Perikanan (KKP), 2019. Dugong terjerat jarring nelayan di Kampung kelam pagi, Dompak Tangjung Pinang. Retrived from: https://kkp.go.id/djprl/ bpsplpadang/artikel/11013-dugong-terjerat-jaringnelayan-di-kampung-kelam-pagi-dompak-tanjungpinang18-05-2019.

Kilminster, K., K. McMahon, M. Waycott, G. A. Kendrick, P. Scanes, L. McKenzie \& J. Udy, 2015. Unravelling complexity in seagrass systems for management: Australia as a microcosm. Science of the Total Environment 534: 97-109.

Kreb, D., 2008. Proyek Lumba Irrawaddy Teluk Balikpapan 2007-2008 Perlindungan dan keragaman hayati cetacean di dan dekat Teluk Balikpapan, Kalimantan Timur, Indonesia Laporan Teknis Akhir. Yayasan Konservasi RASI, Samarinda.

Lanyon, J. M., 1991. The nutritional ecology of the dugong (Dugong dugon) in tropical North Queensland. PhD thesis. Monash University, Melbourne, VIC, Australia. pp 337.

Lee, K. \& K. Dunton, 1996. Production and carbon reserve dynamics of the seagrass Thalassia testudinum in Corpus Christi Bay, Texas, USA. Marine Ecology Progress Series 143: 201-210.

Lee, K. S., S. R. Park \& Y. K. Kim, 2007. Effects of irradiance, temperature, and nutrients on growth dynamics of seagrasses: a review. Journal of Experimental Marine Biology and Ecology 350: 144-175.

Longstaff, B. J. \& W. C. Dennison, 1999. Seagrass Survival during Pulsed Turbidity Events: The Effects of Light Deprivation on the Seagrasses Halodule Pinifolia and Halophila Ovalis. Aquatic Botany 65: 105-121.

Marsh, H., R. I. T. Prince, W. K. Saalfeld \& R. Shepherd, 1994. The distribution and abundance of the dugong in Shark Bay, Western Australia. Wildlife Research 21: 149-161.

Marsh, H., H. Penrose, C. Eros \& J. Hugues, 2002. The Dugong (Dugong dugon). Status report and action plans for countries and territories in its range. UNEP Early Warning and Assessment report 1.

Nishiwaki, M. \& H. Marsh, 1985. Dugong: Dugong dugong (Muller, 1776). In Handbook of Marine Mammals, Academic Press Inc., London: 1-31.

Parsons, M. J. G., D. Holley \& R. D. McCauley, 2013. Source levels of dugong (Dugong dugon) vocalizations recorded in Shark Bay. The Journal of the Acoustical Society of America 134(3): 2582-2588.
Perez-Llorens, J. L. \& F. X. Niell, 1993. Temperature and emergence effects on the net photosynthesis of two Zostera noltii Hornem. morphotypes. Hydrobiologia 254: 53-64.

Preen, A., 1995. Impacts of dugong foraging on seagrass habitats: observational and experimental evidence for cultivation grazing. Marine Ecology Progress Series 124: 201-213.

Preen, A., 1998. Marine protected areas and dugong conservation along Australia's Indian Ocean coast. Environmental Management 22(2): 173-181.

R Core Team, 2018. R: a language and environment for statistical computing. R Foundation for Statistical Computing, Vienna.

Rajamani, L. \& H. Marsh, 2010. Using parallel regional-and local-scale initiatives to inform conservation management of rare wildlife: A case study of the dugong Dugong dugon in Sabah, Malaysia. Endangered Species Research 13(1): 17-23.

Reynolds III, J. E., 1999. Efforts to conserve the manatees. In Twiss, J. R. \& R. R. Reeves (eds), Conservation and Management of Marine Mammals. Smithsonian Institution Press, Washington: 267-295.

Sandoval-Gil, J. M., I. Barrote, J. Silva, I. Olivé, M. M. Costa, J. M. Ruiz, et al., 2015. Plant-water relations of intertidal and subtidal seagrasses. Marine Ecology 36(4): 1294-1310.

Shafer, D. J., T. D. Sherman \& S. Wyllie-Echeverria, 2007. Do desiccation tolerances control the vertical distribution of intertidal seagrasses? Aquatic Botany 87: 161-166.

Sheppard, J. K., A. R. Preen, H. Marsh, I. R. Lawler, S. D. Whiting \& R. E. Jones, 2006. Movement heterogeneity of dugongs, Dugong dugon (Müller), over large spatial scales. Journal of Experimental Marine Biology and Ecology 334: 64-83.

Sheppard, J. K., I. R. Lawler \& H. Marsh, 2007. Seagrass as pasture for seacows: landscape-level dugong habitat evaluation. Estuarine, Coastal and Shelf Science 71: 117-132.

Sheppard, A. J. K., R. E. Jones, H. Marsh \& I. R. Lawler, 2009. Effects of tidal and diel cycles on Dugong habitat use effects of tidal and diel cycles on Dugong habitat use. BioOne Complete 73: 45-59.

Sheppard, J. K., H. Marsh, R. E. Jones \& I. R. Lawler, 2010. Dugong habitat use in relation to seagrass nutrients, tides, and diel cycles. Marine Mammal Science 26: 855-879.

Sidik, J. B., Z. Muta Harah, A. Mohd. Pauzi \& S. Madhavan, 1999. Halodule species from Malaysia - Distribution and morphological variation. Aquatic Botany 65(1-4): 33-45.

Tanaka, Y. \& M. Nakaoka, 2004. Emergence stress and morphological constraints affect the species distribution and growth of subtropical intertidal seagrasses. Marine Ecology Progress Series 284: 117-131.

Tol, S. J., R. G. Coles \& B. C. Congdon, 2016. Dugong dugon feeding in tropical Australian seagrass meadows: implications for conservation planning. PeerJ 4:

Unsworth, R. K. F., M. A. Rasheed, K. M. Chartrand \& A. J. Roelofs, 2012. Solar radiation and tidal exposure as environmental drivers of Enhalus acoroides dominated seagrass meadows. PLoS ONE 7: 1-8.

Yamamuro, M. \& A. Chirapart, 2005. Quality of the seagrass Halophila ovalis on a Thai intertidal flat as food for the Dugong. Journal of Oceanography 61: 183-186. 
Zamzani, 2017. Dugong ditemukan mati dan dipotong-potong di sungai sempur rupat Riau. Mongabay. Retrived from: https://www.mongabay.co.id/2017/09/30/dugong-

ditemukan-mati-dan-dipotong-potong-di-sungai-sempurrupat-riau/.

Zuur, A. F., E. N. Ieno \& C. S. Elphick, 2010. A protocol for data exploration to avoid common statistical problems. Methods in Ecology and Evolution 1(1): 3-14.
Publisher's Note Springer Nature remains neutral with regard to jurisdictional claims in published maps and institutional affiliations. 